\title{
EVALUASI PROGRAM PEMBINAAN OLAHRAGA PRESTASI CLUB BADMINTON JUANDA SPORT CENTER KOTA SUNGAI PENUH BERBASIS CIPPO
}

\author{
Rafi Suganda', Donie², Gusril', Ishak Aziz", Damrah ${ }^{5}$ \\ 1,2,3,4,5 Fakultas IImu Keolahragaan, Universitas Negeri Padang \\ E-mail: rafisuganda2@gmail.com¹, donie.fik.unp@gmail.com², gusrilnasir@gmail.com³, \\ 60ishakaziz@gmail.com ${ }^{4}$, damrahburhan@yahoo.co.id ${ }^{5}$ \\ DOI: https://doi.org/10.36526/kejaora.v6i2.1409
}

\begin{abstract}
ABSTRAK
Berdasarkan pengamatan, ditemukan menurunnya prestasi olahraga Club Badminton Juanda Sport Center, diduga program latihan yang diberikan kepada atlet kurang berjalan secara maksimal. Hal ini bisa mengakibatkan prestasi Club Badminton Juanda Sport Center sulit untuk mencapai prestasi yang diharapkan. Tujuan penelitian adalah mengevaluasi program pembinaan Club Badminton Juanda Sport Center. Penelitian ini mengunakan pendekatan kualitatif dengan pengumpulan data secara kualitatif deskriptif, dengan menggambarkan kegiatan yang berlangsung di lapangan secara terfokus dan kompleks. Yang menggambarkan keseluruhan program pembinaan Club Badminton Juanda Sport Center mencakupi dari segi metode CIPPO (Context, Input, Process, Product, Outcome). Data diperoleh melalui observasi, wawancara dan dokumentasi. Hasil penelitian menunjukkan program pembinaan olahraga prestasi Club Badminton Juanda Sport Center ditinjau dari context sudah cukup efktif. Program pembinaan ditinjau dari input kurang efektif, terutama dalam kualitas pelatih serta atlet. Program pembinaan ditinjau dari process juga kurang efektif, khususnya pelaksanaan program latihan dan pengawasan. Program pembinaan ditinjau dari segi product cukup efektif dan program pembinaan ditinjau dari outcome cukup efektif. Secara keseluruhan, program pembinaan olahraga prestasi tergolong kurang efektif dan perlu dilakukan revisi program. Berdasarkan hasil evaluasi program pembinaan, yang perlu menjadi prioritas utama club badminton Juanda Sport Center untuk meningkatkan prestasi atlet badminton adalah peningkatan waktu latihan dan kualitas pelatih.
\end{abstract}

Kata Kunci: Evaluasi Program, Pembinaan Olahraga Prestasi, CIPPO

\section{PENDAHULUAN}

Bulutangkis merupakan salah satu dari sekian banyak cabang olahraga yang berkembang saat ini yang perlu mendapatkan proses pembinaan yang lebih baik. Secara garis besar unsur teknik permainan bulutangkis itu dapat dikelompokkan menjadi empat bagian besar yaitu: a. Teknik memegang raket (grip), b. Teknik footwork, c. Teknik penguasaan pukulan (stroke), $d$. Teknik penguasaan pola-pola permainan (Donie, 2009). Bulutangkis di Sungai Penuh sebagai olahraga prestasi yang telah banyak mendapatkan perhatian besar dari masyarakat, hal ini dibuktikan dengan adanya dukungan terbesar dalam bentuk wadahwadah program pembinaan atlet usia dini oleh Pengurus Cabang Persatuan
Bulutangkis Seluruh Indonesia di setiap Kota dan Kabupaten. Sekolah atau diklat adalah suatu wadah program pembinaan atlet bulutangkis usia dini yang keberadaanya memainkan peranan penting, karena para pesertanya adalah anak-anak usia sekolah yang merupakan bibit-bibit atau sumber daya manusia yang sangat diharapkan bagi perkembangan prestasi olahraga bulutangkis di masa mendatang, terlebih ditengah menurunnya prestasi bulutangkis Nasional di tingkat Internasional.

Demi tercapainya prestasi olahraga, khususnya pada olahraga bulutangkis maka perlu adanya sebuah pembinaan yang terstruktur dengan baik. Aszari \& Raharjo (2015) mengatakan,"prestasi olahraga yang optimal dapat dicapai dengan pembinaan 
Jurnal Kejaora: Jurnal Kesehatan Jasmani dan Olah Raga

ISSN: 2541-5042 (Online)

ISSN: 2503-2976 (Print)

Volume 6 Nomor 2, Edisi November 2021

yang baik dan benar disertai dengan latihan fisik, teknik mental. Pembinaan yang teratur, sistematis, terprogram dan berkesinambungan dengan pendekatan ilmu pengetahuan dan teknologi yang diterapkan dalam program latihan, sehingga dapat meningkatkan kualitas kemampuannya".

Santoso et al., (2017) mengatakan bahwa "salah satu strategi yang paling mendasar dalam upaya mewujudkan sumber daya manusia Indonesia khususnya di bidang olahraga adalah dengan memusatkan perhatian dan orientasi pembangunan olahraga sedini mungkin yakni dengan melakukan pembinaan dan pengembangan olahraga bagi generasi muda sejak dini". Namun, Suparmin (2015) mengatakan,"pembinaan olahraga prestasi, merupakan masalah yang rumit dan kompleks dan banyak tergantung serta dipengaruhi berbagi faktor. Pembinaan olahraga tidak cukup mengandalkan dana, pengorganisasian adalah peran dari pendekatan ilmiah berbagai disiplin ilmu".

Program pembinaan yang baik dan benar, disertai latihan fisik, teknik dan mental merupakan faktor penting yang harus diperhatikan. Muharram (2016) mengatakan,"dalam upaya menyusun program latihan untuk meningkatkan prestasi harus meningkatkan empat aspek yaitu (1) aspek fisik, (2) teknik, (3) taktik, dan (4) aspek mental. Keempat aspek tersebut harus dilatih dengan cara dan metode yang benar agar setiap aspek dapat berkembang secara maksimal". Kondisi fisik merupakan satu persyaratan yang sangat diperlukandalam usaha peningkatan prestasi seorang atlet, bahkan sebagai landasan titik tolak suatu awalan olahraga prestasi.

Perkembangan olahraga bulutangkis di Sungai Penuh termasuk dalam kategori kurang baik, karena cabang olahraga bulutangkis tidak pernah menjuari kejuaraan bergengsi seperti PON atau PORWIL di kejuaraan PORPROV pun Sungai Penuh hanya bisa sampai pada tahap penyisian. Hal ini menunjukkan, bahwa kepengurusan PBSI di Sungai Penuh tidak bekerja secara maksimal untuk melahirkan atlet-atlet pebulutangkis muda di Juanda Sport Center, Kota Sungai Penuh.

Program pembinaan menunjukkan suatu yang diorganisasi dengan tidak baik, secara metodologi dan menurut prosedur ilmiah sehingga dapat membantu para atlet untuk mencapai hasil yang lebih baik berdasarkan latihan dan prestasinya. Oleh karena itu, perencanaan merupakan alat yang sangat penting yang dapat dipakai oleh seorang pelatih dalam usaha mengarahkan program latihan yang terorganisir dengan baik. Dalam menciptakan dan menghasilkan atlet yang berprestasi dalam olahraga bulutangkis dibutuhkan peranan pelatihan yang melibatkan berbagai unsur diantaranya: pemerintah, peran dari masyarakat, dapat menjadi motivasi bagi para atlet untuk mengembangkan kemampuan dan potensi sebagai atlet bulutangkis khususnya, di Club Juanda Sport Center Kota Sungai Penuh.

Dari beberapa Club yang ada di Kota Sungai Penuh, khususnya Club bulutangkis Juanda Sport Center Kota Sungai Penuh memiliki Club yang dibentuk untuk mengembangkan kemampuan anak sampai meningkatkan prestasi anak, diantaranya untuk mengikuti pertandingan single event seperti Kejurda, Kejurwil, Kejurnas, maupun multi event PON Remaja, PorKab/Kota, PorProv, Porwil, PON maupun ajang-ajang kompetisi lainnya yang ada di Kabupaten/Kota, Provinsi. Dari berbagai event tersebut bahwa prestasi yang diperoleh Club Juanda Sport Center Kota Sungai Penuh masih belum memuaskan.

Berdasarkan hasil observasi dan hasil wawancara terhadap pelatih kepala bulutangkis Juanda Sport Center Kota Sungai Penuh mengatakan bahwa, jumlah atlet yang dibina mencapai 22 orang. Kemudian, prestasi bulutangkis atlet putra maupu putri belum menunjukkan prestasi yang maksimal. Hal ini terlihat, pada kejuaraan PORPROV XXI Provinsi Jambi, Muaro Bulian 28 Mei - 9 Juni 2015 tidak ada satupun atlet yang meraih gelar juara. Kemudian pada ajang PORPROV ke- XXII Provinsi Jambi, Kota Jambi bulan November 2018 lalu, baik atlet putra maupun atlet putri tidak ada yang berhasil meraih podium dan hanya sampai pada babak penyisihan. Sehingga dari berbagai event tersebut, jelaslah belum ada prestasi yang maksimal dari keseluruhan atlet Juanda Sport 
Jurnal Kejaora: Jurnal Kesehatan Jasmani dan Olah Raga

ISSN: 2541-5042 (Online)

ISSN: 2503-2976 (Print)

Volume 6 Nomor 2, Edisi November 2021

Center Kota Sungai Penuh. Berdirinya club bulutangkis Juanda Sport Center dengan fasilitas atau sarana dan prasarana yang baru dan sudah cukup memadai dengan adanya hal tersebut supaya atlet lebih bersemangat dalam menjalankan latihan dan mendapatkan prestasi yang maksimal.

Tujuan evaluasi program merupakan suatu peran penting dalam mengumpulkan, memberi informasi dalam mengambil suatu kebijakan, keputasan serta mengkomunakasikan terlaksananya kegiatan program kinerja sehingga dapat diketahui seberapa tinggi tingkat keberhasilan program yang direncanakan. Dari beberapa model evaluasi program maka peneliti menggunakan Model yang digunakan dalam mengevaluasi program adalah model CIPPO (Context, Input, Process, Product, dan Outcome) yang dikembangkan oleh Stufflebeam dan Gilbert Sax atau model yang disempurnakan dari model Crabbè \& Leroy (2008). Model ini disusun secara sistematis agar setiap komponen dapat terlihat penilaianya dengan tujuan untuk melengkapi dasar pembuatan keputusan dalam evaluasi program dengan analisis yang berorientasi pada perubahan terencana.

\section{METODE}

Pendekatan yang digunakan dalam penelitian ini adalah pendekatan kualitatif. Barlian (2020) penelitian kualitatif adalah penelitian yang bermaksud untuk memahami fenomena tentang apa yang dialami oleh subjek penelitian, misalnya: perilaku, persepsi, motivasi, tindakan dan lain-lain secara holistik dan dengan cara deskripsi dalam bentuk kata-kata dan bahasa, pada suatu konteks khusus yang alamiah dan dengan memanfaatkan berbagai metode alamiah. Informan penelitian adalah 1 orang pengurus, 1 orang pelatih dan beberapa atlet yang mengerti tentang bandminton dan pernah menjuarai kejuaraan dari club badminton Juanda Sport Center.

Untuk memperoleh data dalam penelitian ini, digunakan alat pengumpul data berupa observasi, observasi digunakan oleh para evaluator dengan cara melihat dan merasakan sendiri terhadap hal yang telah dilakukan subjek atau objek yang dievaluasi".

Dalam observasi, evaluator biasanya menggunakan alat bantu seperti misalnya alat perekam audio visual untuk memaksimalkan perolehan data observasi. Tujuan menggunakan alat bantu ialah untuk memaksimalkan perolehan data evaluatif sehingga dapat diperoleh hasil yang maksimal tentang program atau proyek yang dinilai. Wawancara adalah percakapan dengan maksud tertentu. Percakapan itu dilakukan oleh dua pihak, yaitu pewawancara (Interviewer) yang mengajukan pertanyaan dan terwawancara (Interviewee) yang memberikan jawaban atas pertanyaan itu. Wawancara yang dilakukan adalah wawancara tidak terstruktur untuk mengetahui secara mendalam dari responden tentang pelaksanaan program pembinaan atlet badminton Juanda Sport Center Kota Sungai Penuh.

Tempat penelitian ini akan dilaksanakan di club badminton Juanda Sport Center. Waktu penelitian di laksanakan pada bulan Februari 2021.Teknik analisis data dalam penelitian ini di lakukan secara deskriptif kualitatif, dan diperoleh dari hasil wawancara untuk selanjutnya akan dianalisis untuk menilai apakah data yang diperoleh sesuai dengan dibutuhkan dalam penelitian ini.

\section{HASIL DAN PEMBAHASAN}

Club Juanda Sport Center melaksanakan latihan berdasarkan jadwal yang telah ditetapkan jadwal yang di terapkan selama satu minggu lima kali latihan yaitu hari senin, selasa, rabu, kamis, dan jumat. Program pembinaan lima kali dalam satu minggu melakukan latihan fisik,latihan teknik, namun belum berjalan dengan baik terlihat saat peneliti atlet belum maksimal melakukan aktivitas berdasarkan intruksi dari seorang pelatih baik itu latihan fisik maupun latihan teknik. Peneliti melihat kehadiran dari atlet untuk latihan tidak maksimal hanya ada beberapa atlet yang rutin untuk melaksanakan latihan lima kali seminggu.

Untuk menjalankan suatu pembinaan bukan hanya dilihat dari satu faktor dari pelatih ataupun atletnya namun dilihat juga dari faktor sarana dan prasarana yang memadai baik itu bersifat abadi maupun 
Jurnal Kejaora: Jurnal Kesehatan Jasmani dan Olah Raga

ISSN: 2541-5042 (Online)

ISSN: 2503-2976 (Print)

Volume 6 Nomor 2, Edisi November 2021

bersifat sementara, seperti dilihat di lapangan bulutangkis Juanda Sport Center sekaligus dari hasil wawancara peneliti dengan pengurus, pelatih,atlet, dan orang tua untuk sarana dan prasarana club Juanda Sport Center sudah cukub baik. Kondisi lapangan yang terdiri dari enam lapangan yang sudah memiliki standar Nasional dan untuk alat-alat latihan kondisi fisik sudah hampir tercukupi serta sudah memiliki fasilitas yang lengkap.

Dilanjutkan lagi untuk sekarang telah berhasil mengelar beberapa pertandingan kejuaraan seperti pertandingan Kabupaten dan seKota Sungai Penuh pada tahun 2020 dan 2021. Dan sampai sekarang atlet-atlet bulutangkis Club Juanda Sport Center masih aktif mengikuti latihan sampai saat ini berjumlah 22 orang.

\section{Hasil Evaluasi}

1. Evaluasi Pelaksanaan Program Latihan Bulutangkis di Club Juanda Sport Center Ditinjau dari Komponen Context

Evaluasi context dilakukan melalui pengamatan observasi dan wawancara. Berikut merupakan hasil evaluasi mengenai tujuan dan landasan pembuatan program latihan yang dilakukan dengan menganalisis program terakhir. Dari hasil analisis sebelumnya akan membantu para pelatih dalam merancang program selanjutnya. Dan dengan melihat faktor-faktor yang ikut mempengaruhui pelatih dalam merancang program seperti kebutuhanmasing-masing atlet dan disesuaikan dengan tujuan dari latihan yang dilakukan.

Evaluasi context pelaksanaan program latihan difokuskan pada analisis lingkungan program, yaitu adanya dukungan sosial dan ekonomi, berdasarkan dari hasil wawancara dan observasi peneliti dengan pelatih,pengurus, dan atlet dukungansudah begitu baik dariClub Juanda Sport Center memfasilitasi kondisi lapangan yang sudah sangat memadai.

\section{a. Dasar (kebijakan) pelatih dalam merancang program latihan Bulutangkis di Club Juanda Sport Center}

Dasar dalam merancang program latihan menurut hasil wawancara dengan pengurus,pelatih bahwa dasarnya harus menyesuaikan dengan visi dan misi club serta tujuan dari club melakukan latihan bulutangkis. Berdasarkan wawancara dengan atlet juga disebutkan bahwa Visi club Juanda Sport Center adalah menjadi pusat pembinaan olahraga bulutangkis untuk mengasah kemampuanatlet-atlet bulutangkis supaya menjadi atlet yang berkualitas dan berprestasi. Dan dengan Misi untuk melahirkan pebulutangkis berprestasi di tingkat Provinsi maupun Nasional. Bisa di lihat di (lampiran 6,7, dan 8).

Club Juanda Sport Center melakukan pembinaan dengan tujuan menghasilkan atlet yang mampu bersaing di tingkat Provinsi maupun Nasional. Suatu prestasi tidak akan maksimal kecuali dengan adanya latihan. Dan latihan tidak akan berjalan dengan baik tanpa adanya program latihan yang dirancang oleh pelatih. Program latihan disesuaikan dengan kemampuan atlet. Diantaranya faktor yang menjadi patokan salah satunya adalah lamanya atlet melakukan latihan. Sampai dimana kemampuan atlet tersebut baik segi fisik maupun segi teknik.

\section{b. Tujuan Pelaksanaan Program Latihan Bulutangkis di Club Juanda Sport Center}

Evaluasi context mengenai tujuan pelaksanaan program latihan di club Juanda Sport Center yang dapat dihimpun peneliti berdasarkan observasi,wawancara langsung dan dokumentasi selama peneliti bergabung ke dalam lingkungan club dapat di lihat dari hasil wawancara. Menurut Zaka sebagai pelatih mengatakan:

"Tujuan pelaksanaan latihan untukmeningkatkan kemampuan fisik, teknik, dan keterampilan bagi atlet, serta para atlet yang latihan juga mendapatkan dorongan yang penuh dari orang tua mendapatkan izin dari orang tua masing-masing, sehingga latihan dapat berjalan lancar. Latihan disesuaikan dengan target yang diharapkan pelatih kepada tiap-tiap atlet. Dengan tujuan bahwa harus ada 
Jurnal Kejaora: Jurnal Kesehatan Jasmani dan Olah Raga

ISSN: 2541-5042 (Online)

ISSN: 2503-2976 (Print)

Volume 6 Nomor 2, Edisi November 2021

peningkatan baik itu kualitas gerakan dan peningkatan prestasi atlet".

Setelah peneliti observasi melihat langsung hari demi hari kualitas gerakan atau bermain dari atlet sudah mulai meningakat walaupun ada sedikit gerakan yang belum tapak peningkatannya.

\section{c. Analisis Kebutuhan yang Diperlukan Sebelum Membuat Program Latihan Atlet Bulutangkis Juanda Sport Center Kebutuhan yang dilihat dari} menganalisa program latihan itu di antaranya konsi fisik atlet masih kurang stabil mudah terasa lelah dan untuk kelincahan kaki footwoknya belum begitu meningkat dan belum terlihat. Dari hasil observasi peneliti dan wawancara pelatih pengurus dan atlet kebutuhan sarana-prasarana club Juanda Sport Center sudah dikatakan sudah cukup baik terlihat untuk sarana latihan fisik sudah banyak yang lengkap,seperi cone, shuttlecock, alat fitnes, untuk sarana dan prasarana sudah memadai.

\section{Evaluasi Pelaksanaan Program Latihan Bulutangkis di Club Juanda Sport Center Ditinjau dari Komponen Input}

Dalam penelitian ini, evaluasi input meliputi pengurus, pelatih, atlet, dan saranaprasarana mengenai kelayakan,kualifikasi yang memadai, serta mampu menentukan target pencapain prestasi.

\section{a. Kualifikasi Pelatih dan Atlet}

Evaluasi input mengenai kelayakan dan kualifikasi pelatih dan atlet bulutangkis club Juanda Sport Center. Berdasarkan observasi, wawancara, dan dokumentasi. Wawancara dengan pengurus bulutangkis Juanda Albert di club Juanda Sport Center bahwa untuk kualifikasi atlet cukup baik dari segi kondisi fisik,teknik,taktik,mental. Serta atlet sudah memiliki pengalaman yang cukup baik.

\section{b. Sarana dan Prasarana}

Adapun sarana prasarana club Juanda Sport Center sudah terbilang sangat baik, walaupun masih ada alat-alat latihan fisik yang belum lengkap. Untuk lapangan terlihat sudah memiliki fasilitas yang lengkap.
Dimana atlet,pelatih merasa nyaman dengan keadaan lapangan yang bisa di katakan sudah memadai. Karena Club Juanda Sport Center di bawah kepengurusan Juanda Albert untuk pasilitas lapangan sudah terbilang sudah sangat baik.

3. Evaluasi Pelaksanaan Program Latihan Badminton di Club Juanda Sport Center ditinjau dari komponen Proses

Dalam hal ini akan dilihat tepat tidaknya pelaksanaan suatu program yang telah diterapkan. Evaluasi proses meliputi aspek persiapan, pelaksanaan dan pengawasan program latihan mengenai program latihan di Club Juanda Sport Center yang dapat dihimpun penelitian berdasarkan observasi,wawancara langsung dan dokumentasi selama penelitian bergabung kedalam lingkungan club Badminton Juanda Sport Center dapat dilihat dari hasil wawancara berikut terhadap informasi pelatih, seperti yang diungkapkan berikut ini. Berdasarkan wawancara dengan pelatih Zaka mengatakan :

"Bahwa setiap minggunya ada program untuk teknik maupun untuk latihan fisik. Program fisik yang diberikan kepada atlet meliputi aspek kecepatan, daya tahan, dan kelincahan. Latihan teknik yang dilakukan adalah latihan teknik pada setiap atlet baik pemula maupun lanjutan sama programnya hanya saja perlakukannya berbeda".

Atlet merupakan objek yang menjadi faktor yang berpengaruh terhadap berhasil tidaknya suatu cabang olahraga dapat berprestasi dan merupakan suatu yang mutlak harus dimiliki oleh suatu cabang olahraga, sehinga dapat mencapai prestasi yang optimal. Kenyamanan atlet dalam mengikuti program latihan yang diberikan oleh pelatih menjadi kunci sukses sebuah keberhasilan terkait pernyaatan di atas.

Yang terlihat dari hasil observasi kelapangan untuk program latihan sudah terlaksana, tetapi ada beberapa program latihan fisik dan teknik masih terlihat kurang dikarenakan waktu latihan yang terbilang sangat singkat. Kedisplinan atlet masih dikatakan belum baik setelah peneliti 
observasi atlet banyak terlihat sering terlambat untuk mengikuti latihan. Kedisplinan pelatih sudah terbilang cukup baik, pelatih datang tepat waktunya dikarenakan tempat tinggal dekat dengan lingkungan lapangan jadi pelatihdatang terlebih dahulu kelapangan. Selanjutnya untuk metode yang diberikan pelatih kepada atlet sudah cocok dan bervariasi sesuai dengan rancangan program yang ada, setelah peneliti lihat setelah waktu latihan pelatih memberikan evaluasi latihan apa yang sudah di laksanakan pelatih memberikan evaluasi latihan secara bersama-sama.

\section{Evaluasi Pelaksanaan Program Latihan} Badminton di Club Juanda Sport Center di tinjau dari komponen Product

Dalam penelitian ini, evaluasi product meliputi aspek prestasi yang dicapai dalam keberhasilan program pelatihan yang didapatkan oleh club badminton Juanda Sport Center. Karena keberhasilan program dapat dikatagorikan dalam dua kateria yaitu, hasil dari program dan prestasi nasional.

\section{a. Prestasi Atlet}

Dapat dilihat dari hasil data yang diungkapkan berikut ini.

Hasil wawancara dan hasil observasi dapat peneliti paparkan pelatih mengatakan bahwa :

"Pencapaian prestasi atlet badmintonclub Juanda Sport Center untuk ditingkat Kabupaten dan Kota sudah cukup baik. Secara keseluruhan untuk Kejuaran antar daerah yang dilaksanakan umumnya di Kota Sungai PenuhBadminton Juanda Sport Center selalu meraih juara. Tetapi untuk hasil pertandingan seperti PORPROV yang diadakan di luar Kota Sungai Penuh untuk atletclub badminton Juanda Sport Center belum mampu untuk mendapatkan hasil yang terbaik".

Berdasarkan wawancara peneliti dengan atlet Safiq mengatakan bahwa :

"saya akan berusaha semaksimal mungkin untuk dapat berprestasi di kejuaran berikutnya. Selama program pelatihan saya ikuti saya merasa banyak kemajuan dari sebelumnya baik itu dari aspek fisik maupun teknik. Untuk pertandingan PORPROV yang di laksanakan di luar Kota Sungai Penuh saya belum bisa mendapatkan hasil yang baik".

Banyak faktor yang mempengaruhi hal tersebut diantaranya jam terbang atlet luar lebih banyak waktunya dan bisa membagi waktunya beda dengan atlet badminton Juanda Sport Center rata-rata atlet masih di tingkat junior jam sekolah juga sebagai faktor yang harus di terapkan.

\section{Evaluasi Pelaksanaan Program Latihan Badminton di Club Juanda Sport Center ditinjau dari komponen Outcome}

Dalam penelitian ini, evaluasi outcome meliputi aspek program dan prestasiyang dicapai dalam keberhasilan program pelatihan yang didapatkan oleh club badminton Juanda Sport Center.

\section{a. Program Latihan}

Hasil wawancara dari hasil observasi dapat peneliti paparkan bahwa pencapaian program latihan yang disusun oleh pengurus dan pelatih yang sudah diberikan kepada atlet, sudah cukup baik dilihat dari kemampuan dari setiap atlet dalam memukul bola sudah cukup baikdari sebelumsebelumnya, kemampuan atlet dalam bertanding semakin hari semakin meningkat baik. Hanya saja masih ada yang perlu di perbaiki seperti kedisiplinan atlet dalam latihan. Tetapi hal ini tidak sepenuhnya salah atlet. Setelah peneliti wawancara langsung dengan pelatih dan atlet salah satu kendala kurangnya disiplin karena jarak rumah dengan tempat latihan yang lumayan jauh dan terkadang terhambat akibat faktor cuaca yang kurang bagus.

Setelah peneliti observasi kendala program masih banyak yang tidak terlaksanakan karena waktu latihan yang bisa dibilang singkat dan juga pelatih membatasi waktunya karena jarak tempat latihan dan rumah yang jauh mayoritas atlet yang berlatih di club Juanda Sport Center anak-anak yang masih SD dan SMP. Setelah penjelasan di 
Jurnal Kejaora: Jurnal Kesehatan Jasmani dan Olah Raga

ISSN: 2541-5042 (Online)

ISSN: 2503-2976 (Print)

Volume 6 Nomor 2, Edisi November 2021

atas peneliti menyimpulkan program yang dibuat harus benar-benar disesuaikan dengan kondisi dengan waktu yang cukup agar program bisa terlaksanakan dan mendpatkan hasil yang dinginkan. Menurut penelitikeberhasilan dari program tersebut masih terbilang cukup hanya saja karena bisa dilihat saat latihan masih banyak program yang tidak dilaksanakan.

\section{b. Prestasi Atlet}

Hasil wawancara dan hasil observasi dapat peneliti paparkan bahwa pencapaian prestasi atlet bulutangkis club Juanda Sport Center untuk ditingkat Kabupaten dan Kota Sungai Penuh sangat memuaskan. Secara keseluruhan untuk kejuaraan yang dilaksanakan umumnya di Kota Sungai Penuh club badminton Juanda Sport Center hampir semua selalu meraih mendali walaupun masih ada beberapa yang belum mendapatkan mendali. Tetapi untuk hasil pertandingan seperti kejuaraan yang di adakan di luar Kabupaten dan Kota Sungai Penuhclub badminton Juanda Sport Center belum mampu mendapatkan hasil yang terbaik.

Dari hasil prestasi yang diraih oleh club Juanda Sport Center masih dibilang cukup rendah untuk kejuaraan diluar Kabupaten dan Kota Sungai Penuh hal ini dikarenakan dari program latihan yang sudah dirancang sedemikian rupa oleh pengurus dan pelatih belum begitu berjalan dengan semestinya. Menurut peneliti sesuai dari penjelasan diatas jika hal ini dibiarkan berkelanjutan maka prestasi dari club Juanda Sport Center tersebut tidak akan meningkat, untuk itu program pembinaan club Juanda Sport Center bisa dilanjutkan akan tetapi masih perlu diperbaiki disegi context dan process.

\section{PEMBAHASAN}

Club Juanda Sport Center melaksanakan latihan berdasarkan jadwal yang telah ditetapkan berdasarkan perencanaan yang telah disepakati oleh pelatih dan berjalan berdasarkan program pembinaan jadwal yang di terapkan selama satu minggu lima kali latihan yaitu hari senin, selasa, rabu, kamis dan juma'at. Program

pembinaan lima kali dalam satu minggu melakukan latihan fisik, latihan teknik, namun belum berjalan dengan baik terlihat saat peneliti melakukan observasi atlet belum maksimal melakukan aktivitas berdasarkan intruksi dari seorang pelatih baik itu latihan fisik maupun latihan teknik. Peneliti melihat kehadiran dari atlet untuk latihan tidak maksimal hanya ada beberapa atlet yang rutin untuk latihan lima kali seminggu.

Untuk menjalankan suatu pembinaan bukan hanya dilihat dari satu faktor dari pelatih ataupun atletnya namun dilihat juga dari faktor sarana dan prasarana yang memadai baik itu bersifat abadi maupun bersifat sementara, seperti dilihat di lapangan badminton Juanda Sport Center sekaligus dari hasil wawancara peneliti dengan pelatih, atlet dan orang tua untuk sarana dan prasarana sudah cukub baik. Kondisi lapangan yang sudah sangat baik dan untuk alat-alat latihan kondisi fisik sudah hampir tercukupi serta sudah memiliki fasilitas yang lengkap.

\section{KESIMPULAN}

Berdasarkan pembahasan mengenai pelaksanaan program latihan bulutangkis di club Juanda Sport Center maka dapat disimpulkan.

1. Dari segi context pelatih melakukan analisis kebutuhan masing-masing atlet sebelum merancang program latihan. Pelatih juga menganalisis semua faktor yang ikut mempengaruhi kebutuhan tersebut. Seperti program ini diberikan untuk siapa, berapa lama sudah melakukan latihan, bagaimana kondisi fisik yang atlet miliki, dan juga bagaimana prasarana yang ada di club badminton Juanda Sport Center. Dan pelatih siap membuat program baru perlu mengamati ulang kebutuhan-kebutuhan dari masingmasing atlet.

2. Dari segi input yang ikut berbuat dalam pelaksanaan program latihan ada pelatih,atlet, pengurus dan sarana prasarana. Jika dilihat dari kualifikasi pelatih, pelatih club badminton Juanda Sport Center belum memeiliki sertifikat. Untuk atlet club badminton Juanda Sport Center memiliki kemampuan kondisi fisik 
yang cukup terbilang baik, memiliki pengalaman dalam bertanding juga baik. Segi pengurus, pengurus merupakan orang yang berkecimpung di pengurus badminton. Sarana dan prasarana club badminton Juanda Sport Center dikatakan sudah memiliki sarana yang sudah baik. Tetapi masi ada yang begitu kurang seperti atlat-alat latihan fisik yang belum tercukupi dengan baik.

3. Dari segi process berdasarkan observasi terlihat ada yang tidak sesuai dengan apa yang dilakukan pada saat latihan karena terpengaruh pada situasi tertentu, seperti jadwal sekolah atlet ada yang bertumburan dengan latihan dan terjadinya virus corona menyebabkan banyak tertundanya latihan. Pengawasan program latihan club badminton Juanda Sport Center baik pelatih dan pengurus sudah baik tetapi masih harus diberikan pemahaman mengenai pentingnya program latihan tersebut. Keberhasilan dari proses latihan masih di bilang cukup jauh dilihat dari proses latihan. Setelah peneliti observasi masih ada program latihan yang tidak terlaksanakan seperi latihan teknik taktik. Pengurus dan pelatih harus mengevaluasi lagi dan memberikan solusi agar nanti semua program yang belum tercukupi dan sudah dibuat bisa berjalan sebagaimana mestinya dan tujuan program tersebut bisa dicapai secara maksimal.

4. Dari segi product pencapaian prestasi atlet bulutangkis club Juanda Sport Center untuk ditingkat Kabupaten dan Kota sudah sangat baik. Secara keseluruhan untuk Kejuaran Daerah yang dilaksanakan umumnya di Kota Sungai Penuh club bulutangkis Juanda Sport Center selalu meraih juara. Untuk meningkatkan sikap atlet dalam proses program latihan sudah terlihat baik, mereka bisa menghargai teman dan lawan dalam pertandingan serta bertanding secara sportif. Wawasan atlet selama program latihan sudah baik terlihat pada saat atlet latihan.

5. Dari segi outcome pencapain hasil dari program yang sudah disusun oleh pengurus dan pelatih club badminton
Juanda Sport Center. Untuk meningkatkan dari sikap atlet dari proses program latihan sudah terlihat baik, dari segi gerakan permainan teknik dan taktik sudah cukup baik. Akan tetapi dilihat dari segi proses latihannya masih di bilang jauh dari kata sempurna karena tatlet banyak datang terlamba, dari segi Ekonomi dilihat dari sarana dan prasarana sudah sangat baik seperti tempat latihan yang diberikan sudah standar Nasional. untuk biaya pelaksaanaan latihan atlet iyuran perbulan perkepala untuk berlangsungnya latihan.

6. Secara keseluruhan, setelah dilakukannya evalusi terhadap pelaksaanaan latihan club badminton Juanda Sport Center dapat peneliti simpulkan club badminton Juanda Sport Center Tidak dapat melanjutkan program yang telah dilaksanakan, karena masih banyak program yang belum terlaksanakan. Maka untuk pembinaan club badminton Juanda Sport Center harus bisa di perbaiki maka agar bisa tercapai prestasi secara maksimal. Tentu hal ini bisa merugikan atlet dan orang tua karena latihan tidak berkembang padahal latihan sudah terbilang cukup lama tetapi dengan hasil yang dilakukan tidak sesuai dengan yang diharapkan.

7. Rancangan program pembinaan yang perlu menjadi prioritas utama club badminton Juanda Sport Center untuk meningkatkan prestasi atlet badminton adalah peningkatan waktu latihan dan kualitas pelatih.

\section{DAFTAR PUSTAKA}

Aszari, A. D., \& Raharjo, H. P. (2015). Survei Pembinaan Prestasi Klub-Klub Bulutangkis Di Kabupaten Pemalang Tahun 2014. Journal of Physical Education, Sport, Health and Recreations, 4(5), 1783-1787. https://doi.org/10.15294/active.v4i5.54 60

Barlian, E. (2020). Metodologi Penelitian Kualitatif \& Kuantitatif. Padang: Sukabina Press.

Crabbè, A., \& Leroy, P. (2008). The 
Jurnal Kejaora: Jurnal Kesehatan Jasmani dan Olah Raga

ISSN: 2541-5042 (Online)

ISSN: 2503-2976 (Print)

Volume 6 Nomor 2, Edisi November 2021

Handbook of Environmental Policy

Evaluation. London: Earthscan.

Donie. (2009). Pembinaan Bulutangkis Prestasi. Malang: Wineka Media.

Muharram, N. (2016). Evaluasi Program Latihan Fisik Sepakbola Menggunakan Metode CIPP. Jurnal Efektor, 3(1), 3644.

Santoso, H. P., Rahayu, T., \& Rahayu, S. (2017). Pembinaan Bulutangkis di Kota Magelang ( Penelitian Evaluatif Klubklub Bulutangkis di Kota Magelang ). Journal of Physical Education and Sports, 6(2), 133-140. http://journal.unnes.ac.id/sju/index.php ljpes\%0APembinaan

Suparmin, M. (2015). IDENTIFIKASI FAKTOR FISIK ATLET CABANG BULUTANGKIS. Jurnal IImiah Spirit, 15(1). 